\title{
PENGARUH PROMOSI JABATAN TERHADAP PRESTASI KERJA PEGAWAI PADA KANTOR KECAMATAN BALIK BUKIT KABUPATEN LAMPUNG BARAT
}

\author{
Budi Hariyadi $^{(1)}$, Fahrizi(2), Iwan Zulfikar ${ }^{(3)}$ \\ Fakultas Ekonomi Universitas Sang Bumi Ruwa Jurai \\ Haryadi_budi@gmail.com,fahrizi@fe.saburai.ac.id,iwan.zulfikar@fe.saburai.ac.id
}

\begin{abstract}
Abstrak. Pegawai pada Kantor Kecamatan Balik Bukit Kabupaten Lampung Barat memiliki masalah pada Promosi Jabatan belum berjalan sesuai dengan persyaratan terutama kemampuan dan skill di bidang pemerintahan desa, Prestasi kerja pegawai masih rendah belum optimal sesuai dengan yang diharapkan. Tujuan dari penelitian ini untuk mengetahui pengaruh Promosi Jabatan Terhadap Prestasi Kerja Pegawai Pada Kantor Kecamatan Balik Bukit Kabupaten Lampung Barat. Hipotesis penelitian dinyatakan "Diduga promosi jabatan berpengaruh terhadap prestasi kerja pegawai pada Kecamatan Balik Bukit Kabupaten Lampung Barat". Pengumpulan data penelitian menggunakan teknik sampel penelitian dari 27 responden. Metode penelitian yang digunakan adalah analisis kualitatif dan analisis kuantitatif yaitu regresi linier sederhana. Berdasarkan hasil analisis diperoleh persamaan bahwa $\mathrm{Y}=7.107+0.199(\mathrm{X})$. Hasil pengujian menggunakan rumus $\mathrm{t}$ student, menunjukkan bahwa $\mathrm{t}_{\text {hitung }} 2,124>\mathrm{t}_{\text {tabel }} 1,750$, ini menunjukkan bahwa promosi jabatan berpengaruh terhadap prestasi kerja pegawai.
\end{abstract}

Kata kunci: Jabatan, Kinerja, Prestasi, Promosi.

\section{PENDAHULUAN}

Keberhasilan pencapaian tujuan dalam suatu organisasi tidak terlepas dari kualitas Sumber Daya Manusia yang dimiliki kualitas yang baik akan diperoleh jika organisasi secara sungguh-sungguh memperhatikan serta mengetahui kebutuhan organisasi dan kemampuan karyawannya.Untuk mencapai tujuannya, suatu organisasi harus memiliki individuindividu dengan kualitas yang sesuai, jelas tugas, wewenang, tanggung jawab hubungan dan tata kerjanya. Ini dapat diwujudkan melalui aktivitas- aktivitas menajemen sumber daya manusia yang secara ringkas dapat juga dikatakan sebagai upaya pendayagunaan sumber daya manusia.

Beberapa kondisi yang dapat memberikan dan membangkitkan semangat kerja adalah berupa kepuasan yang diterima oleh pegawai misalnya berupa gaji atau pendapatan atau kompensasi yang diterima oleh pegawai. Selain itu faktor fasilitas yang ada apakah sudah mamadai atau belum, karena dengan adanya fasilitas yang lengkap tentunya para pegawai akan dapat bekerja dengan lebih cepat dan lebih sempurna sehingga akan memberikan motivasi dan menambah kegairahan atau semangat bagi para pegawai. Selain itu tentunya pemimpin suatu organisasi perlu memberikan motivasi atau dorongan kepada pegawainya. Salah satunya dengan cara memberikan promosi jabatan.

Prestasi kerja yang tinggi bagi pegawai sangat diperlukan dalam setiap usaha mencapai tujuan organisasi. Sebaliknya dengan prestasi kerja yang rendah akan sukar untuk bagi satuan kerja untuk mencapai hasil kerja yang maksimal. Pengertian Prestasi Kerja menurut Malayu S.P Hasibuan adalah: "Suatu hasil kerja yang dicapai seseorang dalam melaksanakan tugas-tugas yang dibebankan kepadanya yang didasarkan atas kecakapan, pengalaman, dan kesungguhan serta 
waktu"( Hasibuan, 2011), sedangkan W.J.S Poerwadharminta, menyatakan bahwa prestasi kerja adalah hasil yang telah dicapai, dikerjakan dan sebaginya. (Poerwadharminta, 2012)

Kinerja dianggap sesuatu yang penting, baik bagi organisasi maupun bagi pegawai itu sendiri. Hal ini dikarenakan apabila kinerja dari pegawai meningkat atau relatif bagus, maka pegawai itu sendiri akan mendapatkan kompensasi atau balas jasa yang setimpal dengan kinerja dari pegawai tersebut. Tentu saja kegiatan-kegiatan dapat diselesaikan tepat waktu dan tujuan dapat dicapai dengan baik. Apabila seorang pegawai menganggap bahwa kompensasi yang diberikan oleh perusahaan sesuai dengan yang pegawai harapkan, maka akan dapat memotivasi pegawai untuk meningkatkan kinerjanya.

Fenomena yang terjadi yang ada pada Kantor Kecamatan Balik Bukit Kabupaten Lampung Barat terkait dengan tugas pokok dan fungsi yang harus dijalankan pegawai perlu didukung dengan promosi jabatan sehingga konsisten dalam melaksanakan pekerjaannya. Selain itu perlu juga diberi kebebasan untuk mengembangkan kemampuannya dan juga perlu diberi kesempatan untuk pengembangan karir dan berhak atas kompensasi yang layak dan sesuai dengan prestasi kerja yang dicapainya. Sebagai suatu organisasi dengan struktur organisasi yang jelas tentu saja menyimpan berbagai macam permasalahan diantaranya yang berkaitan dengan kesiapan Sumber Daya Manusia (SDM)-nya untuk menempati suatu jabatan.

Demikian juga pada Kantor Kecamatan Balik Bukit Kabupaten Lampung Barat dimana promosi jabatan merupakan faktor yang sangat berperan dalam menentukan tingkat prestasi seorang pegawainya khususnya. Belum ada secara rinci dan terpadu usaha-usaha yang harus dilakukan untuk mencapai prestasi pegawai yang ada dalam organisasi Kantor
Kecamatan Balik Bukit Kabupaten Lampung Barat dengan mengetahui besarnya pengaruh dari promosi jabatan, maka para pimpinan dan pihak-pihak terkait di lingkungan Kantor Kecamatan Balik Bukit Kabupaten Lampung Barat akan mudah dalam melakukan langkah-langkah pembinaannya.

Berdasarkan fenomena tersebut, maka penulis bermaksud meneliti secara lebih lanjut mengenai penelitian dengan judul : "Pengaruh Promosi Jabatan terhadap Prestasi Kerja Pegawai pada Kantor Kecamatan Balik Bukit Kabupaten Lampung Barat".

\section{KAJIAN TEORI}

\section{Pengertian Promosi Jabatan}

Salah satu dorongan orang bekerja pada suatu organisasi atau perusahaan adalah adanya kesempatan untuk maju. Sudah menjadi sifat dasar manusia pada umumnya untuk menjadi lebih baik, lebih maju dari posisi yang dipunyai saat ini. Kesempatan untuk maju di dalam organisasi sering disebut sebagai promosi (naik pangkat). Kata mutasi atau pemindahan oleh sebagian masyarakat sudah banyak di kenal.

Menurut arti katanya maka istilah pemindahan meliputi segala pemindahan jabatan seorang karyawan dalam arti umum. Jadi ke dalam istilah tersebut termasuk bukan saja perubahan jabatan yang setingkat yang tidak mengurangi/menaikkan baik kekuasaan maupun tanggung jawabnya, tetapi juga promosi (kenaikan) dan demosi (penurunan). Hal ini sesuai dengan batasan yang terdapat di dalam kamus managemen, yaitu pemindahan adalah suatu perubahan dalam penunjukan pekerjaan, pemindahan dapat mengandung kenaikan pangkat, penurunan pangkat/tidak ada perubahan 
dalam status dan tanggung jawab (Moekijat, 2008).

\section{Maksud dan Tujuan Promosi}

Agar semangat kerja pegawai dapat ditingkatkan dalam rangka mencapai tujuan organisasi, perlu diperhatikan kondisi kerja dari pegawai yang bersangkutan, yaitu salah satunya melalui pelaksanaan mutasi. Pelaksanaan mutasi menurut Alex S. Nitisemito (2012 :127), menyatakan bahwa maksud dan tujuan mutasi adalah sebagai berikut :

1. Promosi bertujuan untuk mengusahakan "orang tepat pada tempat yang tepat". Dengan mutasi berarti pimpinan organisasi berusaha memindahkan para pegawai pada tempat pekerjaan lain yang sesuai.

2. Promosi bertujuan untuk menciptakan kerjasama kelompok untuk suksesnya suatu pekerjaan seringkali diperlakukan kekompakan kerja dalam kelompok, mungkin saja seorang pegawai kurang dapat bekerja sama dengan kelompoknya tapi setelah dimutasikan dengan kelompok lain ternyata kerjasama yang baik dapat lebih terjamin.

3. Promosi bertujuan untuk meningkatkan semangat kerja. Pekerjaan yang bersifat rutin dapat menimbulkan rasa bosan sehingga semangat kerja pegawai akan turun, tapi setelah dimutasikan semangat dan kegairahan kerja akan dapat timbul kembali.

4. Promosi untuk mengurangi Labour Turnover. Bila rasa kebosanan untuk mengerjakan suatu pekerjaan tertentu telah memuncak, maka hal ini tidak hanya akan menurunkan semangat kerja tetapi juga menimbulkan keinginan dari pegawai tersebut untuk keluar. Dan untuk mengatasi hal ini bila promosi belum mengizinkan maka mutasilah salah satu jalan keluarnya.

\section{Pengertian Prestasi Kerja}

Pengertian Prestasi Kerja menurut Malayu S.P Hasibuan (2011) adalah: "Suatu hasil kerja yang dicapai seseorang dalam melaksanakan tugas-tugas yang dibebankan kepadanya yang didasarkan atas kecakapan, pengalaman, dan kesungguhan serta waktu". W.J.S Poerwadharminta (2011) menyatakan bahwa prestasi kerja adalah hasil yang telah dicapai (dilakukan), dikerjakan dan sebaginya. Sedangkan Alex S.Nitisemito (2012) mengemukakan prestasi kerja adalah sebagai berikut: "Prestasi kerja adalah hasil kerja yang dicapai oleh seseorang dalam melaksanakan tugas dan pekerjaan yang dibebankan kepadanya".

Pada organisasi yang besar maupun yang sederhana prestasi kerja pegawai perlu dijadikan pedoman dalam melakukan promosi jabatan sehingga berdaya guna bagi organisasi. Menurut Melayu S.P Hasibuan (2011) prestasi kerja adalah suatu hasil kerja yang dicapai dalam melaksakan tugas-tugasnya atas kecakapan usaha dan kesempatan.

\section{Faktor-Faktor Yang Mempengaruhi Prestasi Kerja}

\section{a. Pendidikan}

Dalam meningkatkan prestasi pegawai maka faktor pendidikan sangat berperan penting karena dengan pendidikan yang tinggi dapat membantu pegawai untuk berfikir dan untuk jangka panjang tingkat pendidikan diharapkan dapat mengembangkan pegawai pada masa yang akan datang berupa pengembangan yang lebih baik.

b. Pengalaman kerja

Faktor pengalaman kerja dalam meningkatkan prestasi kerja sangat 
berkaitan dengan pendidikan dan saling menunjang. Untuk tujuan jangka pendek pengalaman kerja sangat dibutuhkan oleh lembaga sebab dengan pengalaman yang lebih banyak diharapkan adanya kemauan yang lebih tinggi dalam bekerja dengan ide yang lebih banyak dan wawasan yang lebih luas.

\section{c. Kecakapan}

Dalam peningkatan prestasi kerja salah satu standar adalah penilaian atas dasar kecakapan setiap pegawai akan menunjukkan kecakapan yang lebih baik jika diberikan kesempatan untuk maju. Sehingga prestasi kerja akan lebih baik lagi. Seorang pegawai dikatakan cakap bila orang tersebut dapat melaksanakan tugas dan tanggung jawab yang telah diberikan oleh atasan kepadanya.

d. Keterampilan

Dalam meningkatkan prestasi kerja keterampilan sangat berpengaruh karena faktor keterampilan berkaitan dengan faktor pendidikan. Apabila pegawai ingin meningkatkan keterampilan maka harus disesuaikan dengan tingkat pendidikannya, perlu diberikan latihan atau kursus keterampilan tertentu.

\section{e. Penghargaan}

Untuk mendorong dan meningkatkan prestasi kerja pegawai serta untuk memupuk kesetiaan terhadap perusahaan maka pada pegawai yang sudah berjasa terhadap perusahaan dan telah menunjukan prestasi kerja yang luar biasa perlu diberikan penghargaan agar pegawai termotivasi untuk bekerja lebih giat lagi. Penghargaan yang dimaksud dapat berupa tanda jasa, kenaikan pangkat, atau bentuk penghargaan lain seperti imbalan berupa materil.

\section{METODE PENELITIAN}

\section{Objek Penelitian}

Objek penelitian ini adalah pegawai di Kecamatan Balik Bukit Kabupaten Lampung Barat, yang beralamat di Jln. Sutan Akbar No.08 Liwa Kecamatan Balik Bukit Kabupaten Lampung Barat. Penelitian ini di laksanakan dari bulan April sampai dengan Juli 2018.

\section{Metode dan Teknik Pengumpulan Data}

Dalam penelitian ini jenis data yang diperlakukan adalah :

a. Data Primer

Data primer merupakan data dasar yang akan diperoleh langsung tanpa perantara orang atau lembaga lain sebagai pihak ketiga. Data primer ini diperoleh dengan wawancara melalui responden dengan menggunakan daftar pertanyaan.

\section{b. Data Sekunder}

Data skunder merupakan data yang diperoleh melalui orang lain yang berhubungan dengan permasalahan yang dipecahkan. Data sekunder ini diperoleh melalui cara studi dokumenter yaitu mengumpulkan dan mempelajari brosurbrosur serta dokumen organisasi.

Langkah-langkah pengumpulan data yang penulis lakukan dengan mengadakan penelitian lapangan yaitu Penelitian yang dilakukan padaKecamatan Balik Bukit Kabupaten Lampung Barat, adapun teknik yang digunakan dalam pengumpulan data adalah dengan :

1. Observasi, yaitu mengadakan survey atau pengamatan langsung kelokasi penelitian.

2. Interview atau wawancara, yaitu mengadakan tanya jawab langsung dengan pegawai pada Kecamatan Balik Bukit Kabupaten Lampung Barat 
3. Dokumentasi, yaitu mengumpulkan dan mencatat dokumentasi yang relevan.

4. Quisioner, yaitu membuat pertanyaan yang berhubungan dengan varibael penelitian.

\section{Sampel dan Populasi}

Untuk menentukan banyak sampel dan populasi, peneliti menggunakan pedoman dari pendapat Arikunto Suharsimi (2010). Apabila subyeknya kurang dari 100, lebih baik diambil semua sehingga penelitiannya merupakan penelitian populasi. Selanjutnya jika jumlah subyeknya besar, dapat diambil $10 \%-15 \%$ atau $20 \%$ - $25 \%$ atau lebih. Adapun jumlah sampel yang diperoleh adalah seluruh populasi di Kecamatan Balik Bukit Kabupaten Lampung Barat, sehingga jumlah populasi berjumlah 27 orang pegawai.

\section{Metode Analisis Data}

Untuk pengolahan data dalam bentuk tabulasi hasil jawaban responden kemudian dilakukan analisis data melalui metode analisis secara kualitatif dan analisa kuantitatif.

Analisis kualitatif merupakan analisis yang dinyatakan dalam bentuk uraian dan didasarkan pada data yang telah ada. Data kualitatif merupakan data berupa informasi yang kemudian dikaitkan dengan data lainnya sehingga memunculkan suatu kebenaran. Analisis ini berguna untuk menjelaskan tentang berbagai macam masalah atau hal-hal penting yang dinyatakan dalam bentuk kalimat.

Analisis kuantitatif yang dilakukan berdasarkan data primer yang diperoleh dari penyebaran instrument (daftar pertanyaan) kepada sampel, dan untuk mengetahui pengaruh dari variabel bebas (independent variable) terhadap variabel terikat (dependent variable).
Persamaan Regresi Linear Sederhana menentukan persamaan regresi linear sederhana untuk X :

$$
Y=a+b X+e
$$

Keterangan:

$$
\begin{aligned}
& \mathrm{Y}=\text { Prestasi Kerja } \\
& \mathrm{a}=\text { Konstanta } \\
& \mathrm{b}=\text { Koefisien regresi } \mathrm{X} \\
& \mathrm{X}=\text { Promosi Jabatan } \\
& \mathrm{e}=\text { Faktor kesalahan }
\end{aligned}
$$

Untuk mengetahui besarnya pengaruh, penghitungan koefisien korelasi tersebut kemudian dilanjutkan dengan Rumus Koefisien Determinasi atau Koefisien Penentu (KP):

$$
K P=(r)^{2} x 100 \%
$$

Untuk menguji secara hipotesis secara parsial digunakan Uji t dengan rumus :

$$
t_{\text {hitung }}=\frac{r \sqrt{N-2}}{\sqrt{1-r^{2}}}
$$

Keterangan:

$$
\begin{array}{ll}
\mathrm{t}_{\text {hitung }} & =\text { Nilai } \mathrm{t} \\
\mathrm{r} & =\text { Koefisien Korelasi } \\
\mathrm{N} & =\text { Jumlah responden }
\end{array}
$$

Kriteria untuk Uji $\mathrm{t}$ adalah sebagai berikut :

a) Jika $t_{\text {hitung }}>t_{\text {tabel }}$ maka Ha diterima dan Ho ditolak.

b) Jika $\mathrm{t}_{\text {hitung }} \leq \mathrm{t}$ tabel maka Ha ditolak dan Ho diterima.

Taraf signifikan dalam penelitian ini digunakan $\alpha=0,05$ atau 5\%. Yang dimaksud dengan Hipotesis nol (Ho) dan Hipotesis alternatif (Ha) adalah :

Ho $=r \leq 0=$ Berarti tidak ada pengaruh promosi jabatan terhadap prestasi kerja 
$\mathrm{Ha}=\mathrm{r}>0=$ Berarti ada pengaruh promosi jabatan terhadap prestasi kerja (Sugiyono, 2008).

\section{HASIL DAN PEMBAHASAN}

Data penelitian yang telah dikumpulkan kemudian diolah untuk menguji kualitas data berupa uji validitas dan reliabilitas. Dari hasil uji validitas yang dilakukan menunjukkan bahwa koefisien korelasi pearson moment untuk setiap item butir pertanyaan dengan skor total variabel promosi jabatan $(\mathrm{X})$, dan prestasi kerja $(\mathrm{Y})$ signifikan pada tingkat signifikan $\alpha 0,05$.

\section{Uji Validitas}

Tabel 1. Hasil Uji Validitas Instrumen Variabel Promosi Jabatan

\begin{tabular}{crrc}
\hline Indikator & r hitung & r tabel & Keterangan \\
\hline X 1 & 0.657 & 0.514 & Valid \\
X 2 & 0.821 & 0.514 & Valid \\
X 3 & 0.930 & 0.514 & Valid \\
X 4 & 0.834 & 0.514 & Valid \\
X 5 & 0.907 & 0.514 & Valid \\
X 6 & 0.741 & 0.514 & Valid \\
X 7 & 0.850 & 0.514 & Valid \\
X 8 & 0.841 & 0.514 & Valid \\
X 9 & 0.777 & 0.514 & Valid \\
X 10 & 0.781 & 0.514 & Valid \\
\hline
\end{tabular}

Berdasarkan Tabel 1. nilai $\mathrm{r}$ hitung promosi jabatan lebih besar dari $\mathrm{r}$ tabel (0.514), sehingga seluruh indikator dinyatakan valid.

Tabel 2. Hasil Uji Validitas Instrumen Variabel Prestasi kerja

\begin{tabular}{cccc}
\hline Indikator & r hitung & r tabel & Keterangan \\
\hline Y 1 & 0.767 & 0.514 & Valid \\
Y 2 & 0.747 & 0.514 & Valid \\
Y 3 & 0.855 & 0.514 & Valid \\
Y 4 & 0.778 & 0.514 & Valid \\
Y 5 & 0.781 & 0.514 & Valid \\
Y 6 & 0.782 & 0.514 & Valid \\
Y 7 & 0.801 & 0.514 & Valid \\
Y 8 & 0.809 & 0.514 & Valid \\
Y 9 & 0.802 & 0.514 & Valid \\
Y 10 & 0.811 & 0.514 & Valid \\
\hline
\end{tabular}

Berdasarkan Tabel 2. hasil perhitungan menunjukkan bahwa seluruh indikator untuk variabel kepuasan kerja adalah lebih besar dari $r$ tabel, sehingga seluruh indikator dinyatakan valid.

\section{Uji Reliabilitas Data}

Uji reliabilitas instrumen menggunakan rumus Cronbach Alpha $(\alpha)$ untuk masing-masing variabel adalah lebih besar dari 0,60. Nilai reliabilitas konsistensi internal ditunjukkan dalam tabel diatas, untuk koefisien Alpha Cronbach dinyatakan reliabel karena lebih besar dari 0,60. Dengan demikian item pengukuran pada masing-masing indikator dalam variabel-variabel penelitian dinyatakan reliabel dan selanjutnya dapat digunakan dalam penelitan.

\section{Analisis Kuantitatif}

Berdasarkan hasil pengujian didapatkan persamaan regresi linier linear sederhana adalah $\mathrm{Y}=7.107+0.199 X$. Nilai konstanta yang diperoleh sebesar 7.107, hal ini berarti bahwa jika variabel independen (promosi jabatan) adalah bernilai nol, maka besarnyaprestasi kerja yang terjadi adalah 7.107. Nilai koefisien regresi variabel promosi jabatan (X) sebesar 0,199, hal ini menunjukkan bahwa setiap kenaikan satu satuan promosi jabatan akan mengakibatkan kenaikan prestasi kerja sebesar 0,199.

Koefisien Determinasi dengan rumus $\mathrm{KD}=\mathrm{R}^{2} \times 100 \%$, hasil pengujian di atas menunjukkan bahwa nilai $R$ square sebesar 0.153 . Nilai $R$ square ini menunjukkan bahwa besarnya kontribusi variabel independen terhadap variabel dependen adalah sebesar $15,3 \%$, sedangkan sisanya sebesar $84,7 \%$ ditentukan oleh variabel lain yang tidak teridentifikasi dalam penelitian ini. 
Pengujian ini dilakukan untuk menjawab model kelayakan hipotesis penelitian. Pengujian dilakukan dengan menggunakan uji $\mathrm{t}$ pada tingkat kepercayaan $95 \%$ atau $\alpha$ sebesar 0.05 , apabila $t_{\text {hitung }}>t_{\text {tabel. }}$. Maka model dinyatakan layak digunakan dalam penelitian ini dan sebaliknya apabila $t_{\text {hitung }}<t_{\text {tabel, }}$, maka model dikatakan tidak layak, atau dengan signifikan (Sig) < 0.05 maka model dinyatakan layak digunakan dalam penelitian ini dan sebaliknya apabila signifikan (Sig) > 0.05 maka model dinyatakan tidak layak digunakan.

Pengujian yang telah dilakukan dapat menjawab hipotesis yang menyatakan "Promosi jabatan berpengaruh terhadap prestasi kerja". Pengujian dilakukan dengan menggunakan uji $\mathrm{t}$ yang menunjukkan bahwa Promosi jabatan berpengaruh terhadap prestasi kerja. Pengujian dilakukan dengan menggunakan uji $\mathrm{t}$ pada tingkat keyakinan signifikansi $\alpha$ 0.05. Dari hasil tabel 4.7dapat diketahui bahwa tingkat signifikansi sebesar $0.044<0.05$ dengan nilai $t_{\text {hitung }}>t_{\text {tabel }}$ yaitu $2,124>1,750$, dengan demikian hipotesis diterima yang berarti promosi jabatan berpengaruh terhadap prestasi kerja.

\section{KESIMPULAN DAN SARAN}

\section{Kesimpulan}

Berdasarkan hasil penelitian dapat disimpulkan bahwa hasil pengujian di atas menunjukkan bahwa nilai $R$ square sebesar 0.153. Nilai $R$ square ini menunjukkan bahwa besarnya kontribusi variabel independen terhadap variabel dependen adalah sebesar $15,3 \%$, sedangkan sisanya sebesar $84,7 \%$ ditentukan oleh variabel lain yang tidak teridentifikasi dalam penelitian ini. Nilai signifikansi sebesar 0,044 lebih kecil dari 0,05. Pengujian dilakukan dengan menggunakan uji t pada tingkat keyakinan signifikansi a 0,05. Dari hasil diketahui bahwa tingkat signifikansi sebesar 0,044 < 0,05 dengan nilai $t_{\text {hitung }}>t_{\text {tabel }}$ yaitu $2,124>1,075$, dengan demikian hipotesis diterima yang berarti promosi jabatan berpengaruh terhadap prestasi kerja pada Kantor Kecamatan Balik Bukit Kabupaten Lampung Barat.

\section{Saran}

Adapun saran yang diajukan peneliti adalah sebagai berikut:

1. Kantor Kecamatan Balik Bukit Kabupaten Lampung Barat hendaknya mempertimbangan pemberian promosi jabatan kepada pegawainya sehingga prestasi kerja pegawai tersebut juga akan meningkat.

2. Kantor Kecamatan Balik Bukit Kabupaten Lampung Barat hendaknya melakukan pendataan pegawai yang akan di promosikan sesuai dengan prestasi kerja pegawai tersebut

3. Kantor Kecamatan Balik Bukit Kabupaten Lampung Barat hendaknya memberikan perhatian kepada pegawai yang mempunyai prestasi di bidang pekerjaannya.

\section{DAFTAR PUSTAKA}

Alex, S. Nitisemito. 2012. Manajemen Personalia. Jakarta: Ghalia Indonesia.

Anityo, Angga Santoso. 2013. Pengaruh Promosi jabatan Terhadap Tingkat Prestasi kerja Karyawan Pada PDAM Tirta Moedal Kota Semarang.

Budiyono. 2009. Metode Penelitian. Bandung: Alfabeta.

Damayanti, Retno. 2012. Pengaruh Promosi jabatan Terhadap Prestasi kerja Karyawan CV. Bening Natural Furniture Di Semarang. 
Ferdinand. 2008. Metode Penelitian dan Survey. Jakarta: Penerbit LP3S.

Hasibuan, Malayu S.P. 2011. Pengantar Manajemen Sumber Daya Manusia. Jakarta: Bumi Aksara.

Moekijat. 2011. Dasar- dasar Manajemen. Jakarta: Ghalia Indonesia.

Pigors, Paul., and Myers, Charles A. 2010. Organisasi dan Manajemen. Diterjemahkan oleh Djoerban Wahid, S. H. Jakarta: Penerbit Erlangga.

Poerwadharminta, W.J.S. 2011. Pengantar Manajemen Perusahaan. Jakarta: CV.Haji Masagung.

Purnamasari. 2008. Penelitian Kuantitatif Program SPSS. Bandung: Binneka Cipta.

Sugiyono. 2008. Penelitian dan Statistik. Yogyakarta: Penerbit BPFE.UGM.

Wijaya, Tanto., dan Andreani, Fransisca. 2015. Pengaruh Promosi jabatan Terhadap Prestasi kerja Karyawan Pada PT Sinar Jaya Abadi Bersama. 